Pamiętnik Literacki 2019, 4, s. 7-18

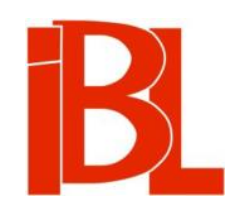

\title{
Krytyka literacka Michała Głowińskiego z
} lat 1954-1962

Adam Poprawa 
1.

$\mathrm{O}$

\author{
$\begin{array}{lllll}J & \mathrm{U} & \mathrm{B} & \mathrm{I} & \mathrm{L}\end{array}$ \\ DOI: $10.18318 / \mathrm{pl} .2019 .4 .1$
}

A

A C

I $\mathrm{E}$

Pamiętnik Literacki CX, 2019, z. 4, PL ISSN 0031-0514

ADAM POPRAWA Uniwersytet Wrocławski

\title{
KRYTYKA LITERACKA MICHAŁA GLOWIŃSKIEGO Z LAT 1954-1962
}

Powołanie Sekcji Krytyki Literackiej w Klubie Krzywego Koła planowane było już od pewnego czasu, jej organizacją zają się Jan Józef Lipski. Zebranie założycielskie odbyło się 10 IV 1957. Pojawili się na nim (podaję w kolejności alfabetycznej) Tadeusz Drewnowski, Michał Głowiński, Andrzej Lam, inicjator Lipski, Konstanty Puzyna, Janusz Sławiński oraz Ryszard Zengel. $Z$ istotnych niewątpliwie powodów nie przyszli Zbigniew Bieńkowski i Andrzej Kijowski, nie było też Henryka Berezy, zainteresowanego pomysłem Lipskiego. Lista obecnych i zgłaszających akces zważywszy zresztą nie tylko na ich późniejsze bibliografie podmiotowe - zapowiadała sekcję doprawdy imponującą. Jednakże następne zebranie praktycznie się nie odbyło, przyszli tylko Głowiński, Lipski i Sławiński. Jak zanotował w swoim dzienniku organizator całego przedsięwzięcia: „Wypiliśmy kawę i pogadaliśmy”. Na ostatnim spotkaniu zakładanej Sekcji Krytyki Literackiej, 13 V, Lipski prowadził dialog już tylko z Głowińskim: zachowane źródła pozwalają wnioskować, że okazali się jedynymi przybyłymi ${ }^{1}$.

Owszem, warto zastanowić się, i byłaby to kwestia niebłaha, dlaczego sekcji nie udało się ukonstytuować, ale nie $z$ tego powodu przypomniałem epizod. Przyczyny nie stanowi również osobliwy urok opowieści o radykalnie redukującym się składzie zespołu ani możliwość potraktowania wydarzenia jako ciekawej metafory społecznej. Historia pojawia się tutaj, gdyż stanowi wystarczający dowód na to, że magister Głowiński, w roku 1957 stypendysta Uniwersytetu Warszawskiego, już pracujący naukowo w Katedrze Teorii Literatury - wcale poważnie myślał o sobie jako o krytyku literackim. A w latach 1954-1962 pisał on i publikował dużo, przede wszystkim recenzji, lecz także szkiców oraz artykułów stricte naukowych. W tym okresie ukazały się również pierwsze książki sygnowane jego nazwiskiem, współautorskie z Aleksandrą Okopień (jeszcze nie Sławińska) i Januszem Sławińskim Wiadomości z teorii literatury (1957) oraz Zarys teorii literatury (1962) z Okopień-Sławińską i Sławińskim tudzież pojedynczego autorstwa Poetyka Tuwima a polska tradycja literacka (1962), czyli drukowana wersja doktoratu.

W roli krytyka literackiego Głowiński debiutował zatem w 1954 roku. Wówczas też wyszedł drukiem tekst Upiory nie strasza o pótnocy, czyli o muzyce $w$ Polskim Radio, ogłoszony w dwutygodniku „Przedpole”, dodatku kulturalnym do „Sztanda-

1 Krótką historię niedoszłej sekcji referuję za: Ł. G a r b a l, Jan Józef Lipski. Bibliografia źródłowa. T. 1. Warszawa 2018, s. 531. 
ru Młodych”. Na upartego dałoby się bronić tezy, w myśl której 1954 oznacza datę podwójnego startu krytycznego: literackiego i muzycznego, tyle że ta druga pasja, nieraz później dokumentowana $\mathrm{w}$ różnych publikacjach i wypowiedziach, nie przerodziła się jednak w systematyczne uprawianie krytyki muzycznej.

Sam Głowiński początek swojej działalności krytycznoliterackiej przesuwa na rok następny, wyznaczając tym samym okres 1955-1962. Wspomina w wywiadzie-rzece: „debiutowałem w połowie 1955 roku w "Twórczości" i przez mniej więcej siedem lat publikowałem w niej systematycznie recenzje, głównie tomików wierszy"

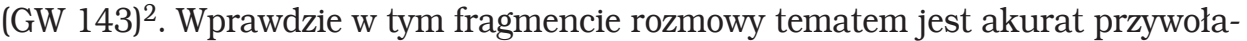
ny miesięcznik, niemniej wzmianka o pierwszej publikacji Głowińskiego w „Twórczości” nabiera sensu uogólniającego: czytelnik może odnieść wrażenie, że chodzi tu zarazem o tekst otwierający całą bibliografię autora. Domysł taki, usprawiedliwiony przez konstrukcje składniową wypowiedzi, nie byłby zbyt odległy od hierarchii, w której badacz postrzega swoje prace z perspektywy ponad półwiecznej. Tak bowiem przedstawia tę kwestię w autobiografii:

Debiutowałem jak wielu w moim fachu recenzjami. Kilkanaście z nich ogłosiłem w „Życiu Literackim", które wówczas uchodziło za pismo w miarę otwarte i liberalne, chętnie publikowali w nim bodaj wszyscy zajmujący się krytyką literacką, to była jego mocna strona. [...] Za właściwy swój debiut uważam omówienie tomu Kazimiery Iłłakowiczówny Poezje 1940-1954, ogłoszone w „Twórczości” w połowie roku 1955. To był początek mojej intensywnej z nią współpracy, trwała ona do końca roku 1962 [...]. [G 209]

Debiut właściwy - w ten sposób autor wyraźnie sugeruje istnienie przynajmniej jednej publikacji wcześniejszej. Znamienne, że wyznaczona przez Głowińskiego cezura powtarza się $\mathrm{w}$ podstawowym źródle bio- i bibliograficznym ${ }^{3}$. Jak można zreszta zasadnie przypuszczać, hasła do tego słownika powstawały nie bez udziału autorów, którym były poświęcone. Rzecz jasna, nie zabrakło tam informacji o pierwszym wydanym tekście Głowińskiego: „Debiutował w 1954 recenzją o Manfredzie A. Rudnickiego, opublikowaną w "Życiu Literackim" (nr 38)"4.

Poza wspomnianymi periodykami Głowiński drukował swoje prace m.in. w „Nowych Książkach”, „Nowinach Literackich i Wydawniczych”, „Współczesności”, „Odrze” i „Pamiętniku Literackim”. Jak już zaznaczyłem, w okresie 1954-1962 zebrało się tych tekstów wiele: bibliografia podmiotowa liczy grubo ponad sto pozycji; zdarzały się numery „Twórczości” zawierające po dwie recenzje Głowińskiego. Jego stosunek do własnych dokonań $z$ tamtych lat jest złożony. $Z$ jednej strony, autor bagatelizuje owe publikacje, uznając je nade wszystko za juwenilia, do których nie warto wracać, $z$ drugiej zaś - sięganie przez innych do tych tekstów raczej

2 Skrótem GW odsyłam do: M. Głow iń ski, G. W ołow i e c, Czas nieprzewidziany. Długa rozprawa bez pana, wójta i plebana. Warszawa 2018. Ponadto stosuję skrót G = M. Głow iń ski, Kręgi obcości. Opowieść autobiograficzna. Kraków 2010. Liczby po skrótach oznaczają stronice. W moim szkicu zajmuję się przede wszystkim właśnie tekstami Głowińskiego o poezji.

3 Zob. J. P[itera], Głowiński Michał. Hasło w: Wspótcześni polscy pisarze i badacze literatury. Słownik biobibliograficzny. Oprac. zespół pod red. J. Czachowskiej, A. Szałagan. T. 3. Warszawa 1994, s. 61.

$4 \quad$ Ibidem. Aczkolwiek jest to informacja omyłkowa: pół roku wcześniej na łamach innego tygodnika M. Głowiński (Przypomnienie Berenta. „Nowa Kultura” 1954, nr 11, s. 7) pisał o pierwszej powojennej edycji Fachowca Berenta. 
sprawia mu satysfakcję. Nie bez przyjemności Głowiński wspomina akceptujące reakcje recenzowanych Mieczysława Jastruna i Julii Hartwig, która swoją uwagę wyraziła pięć dekad po ukazaniu się omówienia w „Twórczości”. Kiedy Agata Stankowska wydała antologię głosów krytycznych dyskutujących z artykułem Jerzego Kwiatkowskiego Wizja przeciw równaniu, Głowiński dziwi się uznaniu redaktorki dla jego polemiki ${ }^{5}$. Ze strony natomiast trzeciej, bo i z takiej da się sprawę zobaczyć, autor nie tyle pozostawia kwestię otwartą, ile ją problematyzuje. W roku 1994 powiedział Annie Nasiłowskiej:

Wspominam to [tj. pisanie do „Twórczości”] dość miło, ale trudno mi o tym mówić, bo moich tekstów z tamtego czasu nie miałem w rękach od dziesięcioleci i nie mam do tego żadnego stosunku. Właściwie nie lubię tych swoich wczesnych kawałków, choć jakiś poziom musiały reprezentować, skoro „Twórczość”, która była wtedy bardzo poważnym pismem, je drukowała ${ }^{6}$.

Kilkanaście lat później, pisząc autobiografię, Głowiński w zasadzie podtrzymuje to stanowisko, choć, jak sądzę, tym razem trochę uchyla czytelnikowi furtkę: „Od niepamiętnych lat do tych moich wczesnych publikacji nie zaglądałem, nic mnie nie skłania, by się w nie zagłębiać, nawet ciekawość, na jakim są poziomie" (G 213). Jeśli autor pośrednio oświadcza, że nie ma zamiaru wzbudzić w sobie zainteresowania jakością swoich starych tekstów, to nie oznacza to identycznej obojętności odbiorcy (może nawet wirtualnego?): takie wyznanie Głowińskiego raczej intryguje czytelnika, który niekoniecznie przechodzi nad tym passusem do porządku. W każdym razie w ciągu kilku następnych lat coś się najprawdopodobniej zmieniło, skoro w rozmowie $z$ Grzegorzem Wołowcem autor zdecydował się powiedzieć kilka słów o swoich juweniliach w sposób znacznie bardziej konkretny niż w komentarzach przytoczonych dotąd:

Jest to krytyka ściśle fachowa, formalistyczna, pod tym względem konsekwentna. Muszę wyznać, że ona mnie zdumiewa z osobistego punktu widzenia. Przeczytałem niedawno wspaniały Dziennik Maksa Frischa. Stwierdza on, że jako młody człowiek zajmował się krytyką literacką; gdy przeglądał swoje wczesne artykuły w wieku dojrzałym, to się dziwił, że on, młody człowiek bez pozycji literackiej, był w stanie formułować autorytatywne sądy. Gdy to przeczytałem, miałem wrażenie, że czytam tekst o sobie. Byłem zakompleksionym, nieśmiałym, trochę zagubionym w świecie młodym człowiekiem. A kiedy siadałem do biurka i pisałem o takim czy innym tomie wierszy, nowel czy - rzadziej - o powieści, to nie miałem oporów i formułowałem opinie tak, jakbym był pięćdziesięcioletnim doświadczonym krytykiem. Jest to dla mnie tajemnica psychologiczna. Dzisiaj bym tak nie pisał. [GW 147-148]

Niewykluczone zatem, iż w międzyczasie Głowiński do swych młodzieńczych tekstów jednak zajrzał. W każdym razie mówi tu o charakterze swoich krytycznoliterackich publikacji oraz ich wyrazistości aksjologicznej. Do obu kwestii przyjdzie jeszcze powrócić.

Sam autor - poza udzieleniem zgody Stankowskiej na zamieszczenie w jej antologii szkicu polemizującego z Kwiatkowskim - zdecydował się po latach na przedruk praktycznie jednego tekstu, mianowicie łącznego omówienia trzech książek

5 Zob. M. Głowiński: G 213; Awangarda i mity romantyczne. W: A. Sta nkowska, „Wizja przeciw równaniu”. Wokół popaździernikowego sporu o wyobraźnię twórczą. Poznań 2013. GW 148-149.

6 Strukturalizm, modernizm i cień marksizmu. Z M. Głowińskim rozmawia A. Na siłowska. „Teksty Drugie” 1994, nr 5/6, s. 11-12. 
Stanisława Jerzego Leca, które znalazło się w piątym tomie Prac wybranych Michała Głowińskiego ${ }^{7}$. Na resztę nałożył edytorskie embargo - mimo propozycji wydania książki $z$ wyborem wczesnych prac: „Uważam, że moje juwenilia powinny sobie spoczywać w spokoju tam, gdzie były opublikowane" (GW 147) ${ }^{8}$. A zatem niniejszy szkic nie może nie być, w pewnym przynajmniej sensie, gestem polemicznym, skoro postanowiłem owe stare recenzje wyciagnąc na światło dzienne.

Przyczyn jest kilka. Tak więc, po pierwsze i oczywiste, każdy tekst wybitnego twórcy zasługuje na dokładną lekturę. Po drugie, 20-letni debiutant był jeszcze studentem warszawskiej polonistyki, 28-letni zaś autor ostatnich tekstów z omawianego okresu posiadał już stopień doktora nauk humanistycznych i pracował w Instytucie Badań Literackich, lata 1954-1962 stanowily zatem dlań istotny czas formacji intelektualnej. Oba powody nie oznaczają, że nieustanna przestrzenią odniesienia będzie cała późniejsza, dojrzała i mająca pełną autorską akceptację literaturoznawcza aktywność Głowińskiego. Przeciwnie, traktuję komentowane tu dalej publikacje jako zbiór o swoistej autonomii, do czego zresztą uprawnia zamykająca data: po roku 1962 Głowiński pisywał teksty krytyczne jedynie sporadycznie. Zaprzestanie działalności systematycznej tłumaczył zarówno innymi zajęciami, jak i ograniczeniami cenzuralnymi uniemożliwiającymi pełną wypowiedź ${ }^{9}$. Po trzecie, aktywność krytycznoliteracka Głowińskiego przypadła na okres intensywnych przemian w powojennej historii Polski: w 1954 roku obowiązywał jeszcze socrealizm, w roku 1962 zaś trudno już było żywić większe nadzieje rozbudzone przez Październik ${ }^{10}$, zarazem jednak trwał pewien model relacji między władzą a kulturą, owszem, zmienny w różnych latach, niemniej wypracowany właśnie w trakcie przełomu oznaczanego skrótowo datą: 1956. Po czwarte, Głowiński zajmuje się krytyką literacką $\mathrm{w}$ dobie formowania się nowoczesnego polskiego literaturoznawstwa. Zbiór tekstów autora $\mathrm{z}$ lat 1954-1962 da się opisać jako jeden ze składników tego procesu.

O fazie, w której znajdowała się wtedy polska nauka o literaturze, świadczą tezy zawarte w recenzji książki Czesława Zgorzelskiego O lirykach Mickiewicza $i$ Stowackiego. Eseje i studia. Tekst Głowińskiego ukazał się w ostatnim zeszycie

7 M. Głow iń s ki, Aforyzmy, fraszki, liryki. W: Intertekstualność, groteska, parabola. Szkice ogólne i interpretacje. Kraków 2000. Prace wybrane Michała Głowińskiego. Red. R. Ny c z. T. 5. Ciekawe zresztą, że w Nocie edytorskiej (ibidem, s. 490), autorstwa zapewne Nycza, miejsce pierwodruku wskazane zostało błędnie: „Myślę, więc jestem...” O Stanisławie Jerzym Lecu. Red. W. Le o p o ld. Kraków 1974. W tamtym tomie znalazł się przedruk szkicu Głowińskiego, pierwodruk natomiast opublikowany został w listopadowym numerze „Twórczości” z 1959 roku. Gwoli ścisłości należy jeszcze odnotować, że pierwszy rozdział książki Poetyka Tuwima a polska tradycja literacka ukazał się najpierw jako artykuł w „Przeglądzie Humanistycznym” (1959, nr 3). Zob. też G 213.

9 Zob. Strukturalizm, modernizm i cień marksizmu, s. 12. - GW 151. Zob. też G 213-214 (Głowiński mówi tu o krytyce swoich dokonań, z którą się spotkał - tym wątkiem się jeszcze zajmę).

10 Niedługo po omawianym okresie M. Gło w iń s ki (Poezja rzeczy małych. „Odra” 1963, nr 2, s. 97. Podkreśl. A. P.) tak zaczął recenzję tomiku S. Chacińskiego: „Jednym z ważniejszych zjawisk w poezji, która swój punkt startowy miała w pamiętnym ta kż e dla liryki roku 1956, była fascynacja rzeczą". Do zagadnień omawianych w tym fragmencie tekstu nie było konieczne wskazanie kontekstu politycznego, niemniej autor uznał za stosowne o tamtych wydarzeniach przypomnieć. „Także” okazuje się partykułą ezopową. 
„Pamiętnika Literackiego” z 1962 roku. Publikacja pochodzi tedy z końca okresu będącego tematem niniejszych uwag, jest istotnym podsumowaniem stanu badań nad literatura i pisania o niej w Polsce - ale warto także na krytycznoliterackie prace Głowińskiego spojrzeć właśnie przez filtr owego podsumowania. Teksty krytyczne i naukowe autora, mimo respektowania przezeń różnic i wymogów obu dziedzin, istotnie się ze sobą łączyły, w tym przede wszystkim sensie, że recenzje i szkice literackie Głowińskiego wynikały z jego literaturoznawczych przekonań, $\mathrm{z}$ tego, jak postrzegał naukę o literaturze. „Krytyka jest przecież b a d a n i e m rzeczywistości literackiej, mimo że niektórzy mienią ją dziedziną sztuki [...]"11 - zauważył niemal en passant kilka lat wcześniej. W omówieniu zaś dzieła Zgorzelskiego formułuje (poniekąd przy okazji) jeszcze bardziej zasadniczy problem, w którym po raz kolejny krytyka rozumiana jest jako działalność nie nazbyt odległa od nauki:

Aby więc stworzyć sytuację sprzyjającą analizie liryki, nie tylko zresztą w pracach ściśle naukowych, ale także w krytyce literackiej, trzeba było zaczać od zadania najbardziej elementarnego: wypracowania takiego języka, który umożliwiałby wyzwolenie spod tyranii potocznych, a tak mylących odczuć ${ }^{12}$.

Autor tłumaczy, że języka takiego dotąd nie było. Do opisu liryki używano nieodpowiednich narzędzi, bezzasadnie próbowano ją interpretować jak utwory fabularne za pomocą streszczenia lub też uznając wiersz za dokument, z którego odczytać się da treści biograficzne czy psychologiczne. To wszystko nazywa Głowiński - zasługującym zresztą na jak najszybsze odrzucenie - językiem potocznym, niezdolnym do interpretacji liryki. Tymczasem ,analiza języka poetyckiego otwiera perspektywę na analizę całości utworu [...."13. Książka Zgorzelskiego oceniona została wręcz entuzjastycznie jako wybitne i nowatorskie dokonanie. Badacz romantyzmu korzystał z ustaleń formalistów rosyjskich, bardzo je rozwijając. Głowiński podkreśla, iż „Zasadniczą kategorią analityczną Zgorzelskiego jest pojęcie podmiotu lirycznego [...]” ${ }^{14}$. Jeśli autor recenzji - drukowanej wszak w „Pamiętniku Literackim"! - powracał w swoim omówieniu do tej kwestii, wyjaśniając jej znaczenie i funkcję, to nie będzie przesadą uznanie początku lat sześćdziesiątych wieku XX za nader jeszcze początkowy etap nowoczesnego literaturoznawstwa w Polsce. Co więcej, wydrukowana w roku 1962 recenzja tomu studiów o Mickiewiczu i Słowackim stanowiła wypowiedź kryptopolityczną (o czym za chwilę). Dzieło Zgorzelskiego otworzyło zatem kwestię analizy literackiej na inne zagadnienia, umożliwiło dalsze poszerzenia:

Poszerzenia, które by wykazywały wagę tego typu badań [analitycznych], które by wykazywały, że - odpowiednio rozszerzane - są one w stanie ogarnąć cały duży obszar problematyki historycznoliterackiej. Poszerzenia, które by z historii form literackich czyniły ogólnie historię literatury, w jakiej forma byłaby pojmowana szeroko, jako swojego rodzaju „ekspresja” różnorakich zjawisk zachodzących w obrębie życia literackiego i przede wszystkim świadomości literackiej ${ }^{15}$.

M. Głowińs ki, „Poeci i inni” Jana Błońskiego. Rec.: J. Błoń ski, Poeci i inni. Kraków 1956. „Twórczość 1957, nr 5, s. 118. Podkreśl. A. P. M. Głowiński, rec.: Cz. Zgorzels ki, O lirykach Mickiewicza $i$ Stowackiego. Eseje i studia. Lublin 1961. „Pamiętnik Literacki” 1962, z. 4, s. 626. 
Nie dotyczy to wyłącznie dyskusji na tematy metodologiczne. Po przełomie październikowym pojawiło się bowiem pytanie, co dalej z marksizmem w badaniach literackich, ideologia sankcjonowana przez państwo, nieskore do jej poniechania. Ustępstwo miało polegać na pozostawieniu w domenie ideologicznej „wielkich spraw - historii, społeczeństwa, związków literatury z ruchami politycznymi i społecznymi”, formalistom zaś wolno zajmować się marginesem, czyli formą właśnie i językiem. W nieco innej wersji, wyrażonej przez Stefana Żółkiewskiego i Marię Janion, strukturalizm mógłby być uprawiany ,jako pomocnicza nauka marksistowskiej historii literatury". Takie podporządkowanie, jak wiadomo, się nie powiodło, i nowoczesne literaturoznawstwo stało się propozycją najistotniejszą i podstawową ${ }^{16}$. Zainicjowanej zaś w roku następnym (1963), jednej z najważniejszych serii książek traktujących o tej dziedzinie humanistyki, zapewne nieprzypadkowo nadano tytuł „Z Dziejów Form Artystycznych w Literaturze Polskiej”.

Zapytany o język swojej krytyki literackiej tudzież o inspiracje, Głowiński, jak można się spodziewać, wskazuje właśnie na analizę jako metodę pisania o literaturze oraz na formalizm (GW 144-145). W autobiografii zaś - wracam do spraw poruszanych wcześniej - nader oryginalnie przedstawia relację między krytyką a nauką:

Moje artykuły i recenzje miały w większości charakter opisowy, brak mi temperamentu krytyka, który formułuje postulaty i gotów jest o nie dzielnie walczyć, choć to, co pisałem, miało wyraźne ukierunkowanie, wynikało $\mathrm{z}$ fascynacji nowatorstwem $\mathrm{i}$ awangarda, a więc tym, co powszechnie nazywano nowoczesnością. Wtedy właśnie któryś z zaprzyjaźnionych kolegów powiedział mi z rozbrajającą szczerością, że to, co piszę, na odległość szeleści papierem. Szeleszczenie papierem jest niewątpliwie wadą w krytyce literackiej, nie jest nią w pisarstwie akademickim, zdałem sobie $z$ tego sprawę - i wnioski wyciagnąłem. [G 213] ${ }^{17}$

Zarzut szeleszczenia papierem wydaje się tak nieznośnie stereotypowy, że aż się prosi o replikę w stylu poetów lingwistycznych: a czym tekst pisany ma szeleścić, jeśli nie papierem? Rozumiem, iż znajomemu Głowińskiego chodziło o (domniemany) brak wyrazistego, mocnego autorskiego ,ja”, które zwykło manifestować swą obecność przy każdej okazji. Owszem, nie był Głowiński krytykiem temperamentnym, choć nie bez wyjątków. W jedynym pamflecie $z$ rozpatrywanego okresu napisał kilka zdań dotyczących Antoniego Słonimskiego, „który odgrywał w swoim czasie pewną rolę, poety, który z pewnością ma jakąś pozycję w dziejach liryki naszego wieku, mimo nawet, że $\mathrm{z}$ jego doświadczeń pisarskich, które nie zawsze mijały się $\mathrm{z}$ anachronizmem, nie wynika dla nowo kształtującej się poezji absolutnie nic" 18 .

Przecież coś takiego mogło wyjść spod pióra Leszka Kołakowskiego (zwracam uwage na role przeczeń i staranność wysłowienia), jednego z najwspanialszych stylistów w całej historii piśmiennictwa polskiego, wysoko cenionego i podziwianego również przez Głowińskiego. Ten drugi przy innej okazji rozpoczął recenzję mocnym aksjologicznym sądem, $\mathrm{z}$ natychmiastowym efektem zaprzeczenia spo-

Z dużą swadą relacjonują tę historię Głowiński i Wołowiec (GW 154-155), których cytuję $\mathrm{w}$ tym akapicie.

17 Wspomniane już w tym szkicu tłumaczenia autora, dlaczego zrezygnował z systematycznego pisania tekstów krytycznych, brzmią wprawdzie przekonująco, niemniej niewykluczone, iż jakiś stopień odpowiedzialności za odłożenie krytycznoliterackiego pióra obciąża anonimowego kolegęe. 
dziewanej pochwały: „Poemat Mandaliana to utwór bardzo ambitny, ale ambicja nie została pojęta najwłaściwiej" ${ }^{19}$. W jeszcze innym miejscu wartościowanie przybiera postać lapidarnej i wcale efektownej formuły, gdy współpracownik „Twórczości” mówi o liryku Janusza Laskowskiego jako o wierszu „bardzo pomysłowym, choć może trochę zbyt elokwentnym"20. A właśnie wypowiedzi wartościujące są niezbywalną cechą krytyki literackiej, rodzaj i skala aksjologicznego licznika świadczą o indywidualności autora. Dość szczegółowego, odległego od zdawkowości, oceniania u Głowińskiego zaś nie brakuje. Zanotowane opinie osłabiają cytowana tezę krytyka o głównie opisowym charakterze jego recenzji, potwierdzają natomiast zauważone podobieństwo do praktyk młodego Frischa.

Głowiński przedstawiał swoje sądy odnoszące się zarówno do poetów startujących, jak i uznanych, modyfikując niekiedy historycznoliteracką pozycję niektórych twórców. W szkicu o Leśmianie (będącym wersją pracy magisterskiej Głowińskiego) potraktował go jako „być może - najoryginalniejszego, najbardziej "samoswojego" poete polskiego XX wieku" ${ }^{21}$. Dziś pod tym zdaniem podpisałoby się wielu, wtedy wyrazy podziwu dla autora Sadu rozstajnego nie były jeszcze tak powszechne. Głowiński wygłasza zresztą tak superlatywny sąd już w pierwszej połowie lat pięćdziesiątych, przyznanie wtedy Leśmianowi palmy pierwszeństwa stanowiło więc gest śmiały również ze względu na cokolwiek futurologiczny charakter owego gestu. Lechonia natomiast określił Głowiński mianem „bardzo przecież konwencjonalnego liryka"22. Upomniał się z kolei, i to już od tytułu począwszy, o istotne miejsce w historycznoliterackiej hierarchii dla Wacława Rolicza-Liedera ${ }^{23}$. Podobnie wypowiadał się na temat autora współczesnego, Zbigniewa Kosińskiego, któremu „należy się lepsza pozycja wśród "poetów 56" [...]"24. Inny i niewątpliwie bardziej doceniany, a na pewno bardziej znany twórca - Lec, ,jako jedyny chyba pisarz współczesny miałby prawo dołączać do swego nazwiska słowo "mędrzecu". Autor szkicu zanotował o nim również szczególnie intrygującą i oryginalną uwagę:

Lec jest chyba najbardziej śpiewnym z poetów współczesnych - każdy prawie jego wiersz ma bardzo wyraźną melodię, subtelną i dyskretną, bo nie opartą o żaden z „melodyjnych” systemów wersyfikacyjnych - ani o sylabotonizm, ani o tonizm ${ }^{25}$.

Przybosia niewątpliwie Głowiński cenił, aczkolwiek (i nie był to jedyny wypadek w jego tekstach) zniuansował ocenę omawianego tomu. W Próbie całości tego poety

M. Głow iń s ki, „Płomienie” - Mandaliana. „Życie Literackie” 1955, nr 6, s. 10.

M. Głowiń ski, Poetyka małoobrazkowa. Rec.: J. La sk ow ski, Siedem lat barwnych. Warszawa 1959. „Twórczość” 1960, nr 4, s. 118.

M. Głowiń ski, Szkic o Leśmianie. Jw., 1956, nr 10, s. 87.

M. Głowiński, rec.: J. Kwiatkowski, Szkice do portretów. Warszawa 1960. „Pamiętnik Literacki” 1962, z. 1, s. 283. Jest to lapidarna polemika ze stanowiskiem recenzowanego autora, który Lechonia cenił wyżej; publikacja zaś pochodzi z periodyku par excellence naukowego, co, jak widać, nie powstrzymało Głowińskiego od dopuszczenia do głosu siebie jako krytyka.

M. Głow iń s ki, Rolicz-Lieder - poeta rewelacyjny. „Nowe Książki” 1961, nr 7, s. 391-392.

M. Głow iń ski, Dwaj poeci. Rec.: Z. Ko sińs ki, Mój anioł lewy. Łódź 1961. - K. Frej dli ch, Alert. Łódź 1961. „Twórczość” 1962, nr 3, s. 137.

M. Głowiński, Aforyzmy, fraszki, liryki. Rec.: S. J. Le c: Myśli nieuczesane. Kraków 1957; Z tysiaca i jednej fraszki. Warszawa 1959; Kpię i pytam o drogę. Kraków 1959. Jw., 1959, nr 11 , s. 126. 
znalazł zatem krytyk „kilka utworów znakomitych” i podał wybrane tytuły ${ }^{26}$. Formy Różewicza z kolei podsumowane zostały tak: „Ten mały zbiór jest chyba książką wyjątkowej wagi, by nie powiedzieć, rewelacją poetycką"27. Komentując zaś jeden z poprzednich tomików tego autora, krytyk stwierdził:

Wśród liryki Uśmiechów jest co najmniej kilka wierszy doskonałych, zajmujących jedno z pierwszych miejsc w całym dorobku poety - przede wszystkim urocze Grzechy, potem Dytyramb na cześć teściowej czy Odwiedziny dziadka ${ }^{28}$.

Jasne, w 1955 roku, kiedy Głowiński czytał ów tom, przed Różewiczem było jeszcze prawie 60 lat pisania, lecz nie o krótszą bibliografię tu idzie: problem bowiem w tym, że również wtedy aż takie wyróżnienie wierszy z Uśmiechów musiało stanowić wartościowanie nie najmniej oryginalne.

W innym miejscu zaliczył krytyk Tymoteusza Karpowicza do „najciekawszej grupy współczesnych poetów polskich, takich jak np. Bieńkowski, Białoszewski, Pogonowska" 29 . W przytoczeniach tych Głowiński niekiedy tonuje jednoznaczność swoich orzeczeń za pomoca wyrażeń typu „chyba” czy „być może”. Po pierwsze więc, decyduje się na wyróżnienie superlatywne, po drugie, sięga po zastrzeżenie. Wydaje się to raczej cechą stylu i myślenia niż ostrożnym zabezpieczaniem przed ewentualną krytyką sądów autora przez odbiorców. Zamiast „być może najoryginalniejszy” czy „chyba jedyny” - mógł był Głowiński napisać np. ,jeden z najoryginalniejszych", ,jeden z bardzo niewielu”, już bez zastrzeżeń. Wolał wszakże napięcie między mocną aksjologia a jej osłabieniem. Myślenie zaś opozycjami jest idea strukturalistyczną... Niemniej u Głowińskiego trafiały się też nader ostre negacje, dwa pierwsze przykłady zapisane zostały, co prawda, w ferworze polemicznym: tak więc Tadeusza Nowaka ze Stanisławem Grochowiakiem obwołał krytyk „tylko trzeciorzędnymi stylizatorami”, a dział poetycki w pewnym dwutygodniku doczekał się miana „produkcji wierszowanej, prezentowanej na łamach pisemka, dumnie nazywającego się "Współczesnością"” 30 . W rzędzie niepochlebnie ocenionych znalazł się też Jerzy Jankowski, wspomniany w recenzji traktującej o innym futuryście:

Utwory Jankowskiego [który za chwilę zostanie nazwany „poetą trzeciorzędnym” - A. P.], gdyby je pisać $z$ respektem dla normalnej ortografii, brzmiałyby jak utwory prawowiernego ucznia Kasprowicza $^{31}$.

Personalna młodopolska paralela, czego można było się spodziewać, jest tu porównaniem pejoratywnym, świadczy przecież o swoistej ciagłości historii literatury.

Tego rodzaju nieoczywiste zestawienia od czasu do czasu u Głowińskiego występowały. W cytowanej przed momentem recenzji tomu Stanisława Młodożeńca

M. Głowiń s ki, Nowy Przyboś. „Przegląd Kulturalny” 1961, nr 26, s. 5.

M. Głowiń s ki, Forma czy tworzenie. „Nowa Kultura” 1959, nr 5, s. 2.

M. Głowiński, „Uśmiechy” Różewicza. Rec.: T. Różewicz, Uśmiechy. Warszawa 1955. „Twórczość” 1956, nr 3, s. 127.

M. Głowińs ki, Liryka fenomenologiczna. Rec.: T. Ka r p ow i c z, Znaki równania. Warszawa 1960. „Odra” 1961, nr 5, s. 98.

M. Głowińs ki, Awangarda i mity romantyczne. „Życie Literackie” 1958, nr 6, s. 10, 11.

M. Głowińs ki, Uwagi o Młodożeńcu. „Nowa Kultura” 1959, nr 50, s. 2. 
autor stwierdził, iż w pewnym okresie twórczości poety „Pojawiają się też gawędy wierszowane, sprawiające wrażenie, że pisał je Wincenty Pol, który czytał Marinettiego"32. Odnosząc się natomiast do utrwalonego przeciwstawiania skamandrytów awangardzie, zauważył, że jeśli za podstawę różnic weźmiemy kwestie ideowe, to „Z dzisiejszego punktu widzenia raczej chyba skłonni jesteśmy widzieć bliższe związki Tuwima z Przybosiem niż np. z Lechoniem" ${ }^{33}$. Z czego bynajmniej nie należy wyciagać wniosku o przedkładaniu przez krytyka idei nad formą (jeszcze o tym wspomnę). Gdzie indziej natomiast mówił Głowiński o konstruktywizmie Leśmiana zbliżającym go do poetów z kręgu Peipera ${ }^{34}$. Recenzję Obrotów rzeczy Białoszewskiego otwiera zaś motto zaczerpnięte $z$ pism Żeromskiego ${ }^{35}$. Historycznoliterackie preferencje Głowińskiego nierozerwalnie łączą się z jego - prawdopodobnie bardziej jednak krytycznoliterackim niż literaturoznawczym - wartościowaniem. Pierwszą przyczynę (tkwi ona w postawie krytyka czy historyka?) trudno by najpewniej wskazać, w każdym razie w wielu miejscach jego prac dają znać o sobie afirmacje i odrzucenia. Sa więc epoki, kierunki, style i zjawiska przywoływane jako negatywny kontekst; nie przepadał zatem autor za ekspresjonizmem, nawrotami romantyzmu, Skamandrem, barokiem oraz - to problem do omówienia za moment - socrealizmem. Intrygował Głowińskiego klasycyzm. Krytyk aprobował natomiast rozwiązania nowatorskie, doceniał i podziwiał wykorzystanie w poezji rejestrów potocznych ${ }^{36}$, lirykę intelektualną, dzieła zdyscyplinowane i konsekwentne, najogólniej: tradycję awangardową uznał za podstawową dla poezji współczesnej. Cytowałem już tu wypowiedź Głowińskiego, który na te idee wskazywał po upływie dekad, mówiąc o swoim młodzieńczym podejściu do literatury. Nowoczesność i awangarda przejawiają się również w szkicach i recenzjach ówcześnie przezeń napisanych. W zorganizowanej na przełomie dekad przez „Współczesność” dyskusji o młodej poezji ujął rzecz lapidarnie: „Doświadczenia awangardy weszły w krwiobieg poezji, oddziałują nawet wtedy, gdy "forma" nie jest już formą awangardową dwudziestolecia" 37 .

Ibidem.

M. Głow iń s ki, Przemiany Mariana Piechala. Rec.: M. Pi e c ha 1, Wybór poezji. Wyd. 2. Warszawa 1955. „Twórczość” 1955, nr 8, s. 119.

Zob. Głowińs ki, Szkic o Leśmianie, s. 80.

Fragment ów brzmi: „Istotna sztuka jest wiekuistym nowatorstwem, funkcją nie ustającego nigdy postępu, więc szczery przyjaciel sztuki i wyznawca postępu nie może być przeciwnikiem najbardziej dziwnego nowatorstwa” (cyt. za: M. Głowińs ki, Spóźnione uwagi o „Obrotach rzeczy”. Rec.: M. Białoszews ki, Obroty rzeczy. Wybór A. Sa nda u er. Warszawa 1956. „Twórczość” 1957, nr 5, s. 125).

Warto w tym miejscu, dla precyzji i swoistej przewrotności stylu krytyka, wynotować dwa zdania zapisane w recenzji Różewiczowskiej Rozmowy z księciem. W podstawowej cesze języka tego autora, kontestującego dotychczasowe normy poetyczności, M. Głowiński (Poeta w słowach oszczędny. „Nowe Książki” 1960, nr 13, s. 774-775) dostrzega „odwagę najwyższą, gdyż jeden nieopatrzny krok, a "niepoetyckość" udawana, celowa - okazać się może autentyczna. O niebezpieczeństwie tym świadczy dobitnie twórczość wielu młodych poetów, dla których Różewicz jest mimowolnym - jak się zdaje - mistrzem”.

Rozmowa o poezji. „Współczesność” 1960, nr 22, s. 4. Głowiński był najmłodszym uczestnikiem debaty, w której prócz niego wzięli udział J. Maciejewski, J. Przyboś i A. Sandauer oraz nie ujawniony $\mathrm{z}$ imienia reprezentant redakcji. 
Głowiński w swoich szkicach i recenzjach po wielokroć krytykował socrealizm. Opisując Narzędzie ze światła Przybosia, kilka zdań poświęcił biegunowej różnicy dzielącej motyw fabryki u tego poety i w „tematyce produkcyjnej”38. Częściej rozprawiał się z problemem za pomocą epitetowego i peryfrastycznego skrótu - co mogło być spowodowane okolicznościami cenzuralnymi (nawet w liberalniejszych czasach październikowego przełomu) - wzmiankując o „ponurych dla naszej literatury latach"39. Rozpoczynając zaś omówienie Uśmiechów Różewicza, wyobraził sobie badacza, który się kiedyś zajmie recepcją twórczości tego poety powstałej w latach czterdziestych i pięćdziesiątych. Zdumienie przyszłego badacza jest mikronarracją skrywająca szyderstwo pod adresem krytyki socrealistycznej ${ }^{40}$.

W tekstach wcześniejszych daje się znaleźć ślady owego nakazowego programu, całkiem zresztą możliwe, że (jak się wtedy zdarzało) są to miejsca doredagowane nie przez autora. Znamienne jednak, że Głowiński dokonuje w tych tekstach radykalnego gestu antysocrealistycznego - konsekwentnie upodrzędnia ideologię względem spraw literackich:

Wiersze powojenne Piechala są dowodem szlachetnego trudu poety, zmierzającego do tworzenia poezji powiązanej z życiem i walką klasy robotniczej, poezji przepojonej ideowością, poezji politycznej. Oczywiście, jest to droga słuszna - świadcząca, że poeta ostatecznie wyszedł ze zbłąkania lat tuż przedwojennych. Powstaje jednak, niestety, szereg zastrzeżeń. Bo tak przekształcając swoją lirykę, Piechal jednocześnie opuścił skrzydła, wyraźnie zniżył lot - tak jakby poezja polityczna zwalniała $z$ dbałości o artystyczne wykończenie wiersza ${ }^{41}$.

Poza poświadczeniem prymatu jakości estetycznych - zbyt dużo w tym passusie pochodzi $z$ socrealistycznego wokabularza, zbyt dużo pedagogicznego pochylenia, by nie dopatrzyć się ironii u 21-letniego Głowińskiego.

Cztery lata po opublikowaniu recenzji zatytułowanej Przemiany Mariana Piechala, w 1959 roku, Alicja Lisiecka - jeśli można posłużyć się hiperbolą - usiłowała nawrócić Głowińskiego na socrealizm. Przyjrzała się mianowicie tekstom młodych krytyków: Głowińskiego - „najwybitniejszego z tej grupy”, Sławińskiego i, częściowo, Kwiatkowskiego. Pochwaliła ich za „brak reklamiarstwa i intelektualnej tandety”, dostrzegła formalistyczne i strukturalistyczne inspiracje (co, rzecz jasna, w przypadku Kwiatkowskiego nie byłoby przedsięwzięciem najłatwiejszym). „Cóż, kiedy krytyka ta nie wiąże się już dziś z niczyim doświadczeniem”, tak tedy „Sławiński i Głowiński [...] rozeszli się z doświadczeniem naszej literatury współczesnej. [...] Krytyka Głowińskiego i Sławińskiego to zamek na szklanej górze, wzniesiony w całkowitej próżni [...]". Lisiecka wskazuje zatem młodym krytykom ograniczenia ich metody, z przekonaniem (własnym) klarując, iż „bez ideologicznych, filozoficznych kryteriów interpretacyjnych" prawdziwej krytyki uprawiać nie sposób, przestrzega Głowińskiego i Sławińskiego, że stosowana przez nich metoda „zacieśnia horyzont badawczy do konfrontowania li tylko osiagnnięć "technik" i "chwytów". Jest jednak

M. Głow iń s ki, Liryka Światowida. Rec.: J. Przy b o ś, Narzędzie ze światta. Warszawa 1958. „Twórczość” 1959, nr 1, s. 130. M. Głowiński, Poeta obrazu. Rec.: J. Śpiewak, Poezje. Warszawa 1955. Jw., 1956, nr 6, s. 149. 
nadzieja: „szansa historyzmu”. Autorka poleca młodym formalistom Stefana Żółkiewskiego, który „w artykule Materiały do bilansu literackiego XX wieku ("Polityka" 1957 [a numer pisma? - A. P.]) rozważa problemy realizmu socjalistycznego w wielkości aspektów literackich i ideologicznych prądu [..."”2 .

Artykuł Lisieckiej stanowi aż nadto wymowny przykład, iż zrelacjonowana przeze mnie wcześniej kwestia autonomii badań literackich (w tym krytyki), uwolnienie ich od marksistowskiej ideologii i kontroli wciąż okazywały się problemem, to nie był pozainstytucjonalny spór o metodologię.

Warto też jeszcze wspomnieć o pamflecie Witolda Dąbrowskiego, który nie zawierał akcentów politycznych, stanowił jednak niespecjalnie przebierająca w środkach szarżę na język Głowińskiego, rzekomą obronę poetów przed krytykami ${ }^{43}$. Zaatakowany nie zwlekał $\mathrm{z}$ odpowiedzią:

W poezji XX w. nie ma [...] żadnego wybitnego poety, który nie zajmowałby się teorią słowa poetyckiego, który nie dążyłby do krytyki słowa zastanego i konstrukcji nowego ${ }^{44}$.

Głowiński podaje przykłady kilku, co podkreśla, rozmaitych poetów, niemniej zacytowane twierdzenie skłonny byłbym uznać za metafore jego programu jako krytyka i literaturoznawcy. Nie ma zatem pisania o literaturze bez ugruntowania teoretycznego. Autor swojego składu zasad nie sformułował jako tekstu osobnego, tezy jego programu da się przecież wydobyć zwłaszcza $z$ recenzji Poetów $i$ innych Błońskiego, w której (przypomnę cytowana już myśl) krytyka zdefiniowana została jako „badanie rzeczywistości literackiej”. Głowiński odwołuje się w tym tekście do systematyki zaproponowanej przez Konstantego Troczyńskiego w Rozprawie o krytyce literackiej. Zarysie teorii, książce wydanej w Poznaniu w 1931 roku, i przedstawia $z$ aprobata podział na „krytykę społeczna, w której dzieło literackie rozważane jest pod kątem społecznego znaczenia [...], często zaś stanowi pretekst do rozważań na tematy inne, krytykę zawartości, badającą utwór pod kątem psychologii itp., oraz krytykę formalną, analizująca go jako samoistną rzeczywistość, strukturę $-z$ punktu widzenia problematyki estetycznej. Tylko temu trzeciemu typowi przypisuje Troczyński walor naukowości i obiektywizmu"45.

Błoński, skądinąd przeczytany przez Głowińskiego z przyjemnością i uznaniem dla walorów stylu, nie spełnia założeń krytyki formalnej. Omawiający zarzuca Błońskiemu „chaos metodologiczny”46. Polemizując z krakowskim autorem, Głowiński przy okazji niektóre ze swoich założeń ujął w celne formuły. Tak więc:

[1] krytyka nie jest sprawą tej czy innej trafnej konstatacji, ale sprawą konstrukcji sylwetki pisarza, przede wszystkim zaś jego stylu;

[2] Forma eseju nie upoważnia [...] do sądów podszytych wiatrem [...];

A. Lisie cka, Propozycje do przyjęcia. „Nowa Kultura” 1959, nr 25, s. 3-4. W następnym numerze tygodnika ukazała się niepodpisana errata: chodziło zatem nie o „realizm socjalistyczny w wielkości”, lecz „realizm socjalistyczny w wielości” (Sprostowanie. Jw., nr 26, s. 4). Jak widać, zdarzają się również polityczne pomyłki freudowskie.

W. D ą br ow s ki, Quatsch mit Sose. „Współczesność” 1960, nr 20, s. 10.

M. Głowińs ki, list do redaktora, z 23 X 1960. Jw., nr 21, s. 12.

Głowińs ki, „Poeci i inni” Jana Błońskiego, s. 120.

Ibidem. Zob. też analizę Gło w i ń s k i e go (rec.: Kw i a t k ow s ki, Szkice do portretów, s. 280-283) dotyczącą napięcia między nauką a krytyką. 
[3] podstawowym zadaniem krytyki jest badanie tej sfery zjawisk, które są specyficznie literackie, właściwe tylko literaturze $[\ldots]^{47}$.

Wracam zatem pod koniec do spostrzeżeń na temat relacji między uprawianymi przez Głowińskiego literaturoznawstwem a krytyką literacką, do przekonania o naukowym badaniu literatury jako stałym odniesieniu dla szkiców i recenzji. Wiele spośród krytycznoliterackich tekstów autora dałoby się rozbudować do solidnych uczonych rozpraw, jego publikacje z „Twórczości” czy innych pism charakteryzują się precyzyjnym skonstruowaniem, od rzetelnego wprowadzenia, gdzie raczej historycznoliteracki wstęp zdecydowanie przesłania - by tak rzecz określić autorskie efekty wejścia; potem pojawiają się tezy, przykłady i argumentacja, aż do podsumowania. Niemniej, co starałem się pokazać, krytyka literacka Głowińskiego jest w pełni autorska, wystarczająco wyrazista pod względem aksjologii i stylu. Do kwestii stylu należy również inwencja terminologiczna badacza, który później wprowadził w obieg tak znane określenia, jak „monolog wypowiedziany”, „odbiorca wirtualny” czy „małe narracje”. W tekstach z czasów młodości też to i owo by się znalazło, pisał bowiem krytyk o „poetyce małoobrazkowej” ${ }^{8}$, „lirycznej metodologii poezji” 49 lub „poetyce intensywnej i ekstensywnej” ${ }^{50}$. Gdyby autor podsumował na początku lat sześćdziesiątych swoją działalność krytyczną, wydając książkę zbierającą sporą liczbę rozproszonych recenzji oraz szkiców, ten drugi zestaw terminów byłby pewnie nie mniej znany niż pierwszy. I częściej by przywoływano wczesne teksty Głowińskiego o Białoszewskim, Lecu, Różewiczu, Przybosiu oraz innych.

\author{
Abstract \\ ADAM POPRAWA University of Wrocław \\ ORCID: 0000-0003-4415-037X
}

\title{
MICHA£ GLOWIŃSKI'S LITERARY CRITICISM FROM THE YEARS 1954-1962
}

Between 1954 and 1962 Michał Głowiński wrote many reviews and literary-critical sketches and published them mainly in "Twórczość" ("Creativity") and "Życie Literackie" ("Literary Life"). After that time, he was not consistent in reviewing the newest literary editions. The period in question is also the first stage of Głowiński's scientific endavour, the moment of forming the modern Polish literary studies, and a time of strong political, social, and cultural changes in Poland. The paper sees Głowiński's literarycritical papers from that period as a relatively autonomous entity. The interpretation if this collection leads to reconstructing Głowiński's literary-critical views, including those on axiology, and to grasping its coherence. In addition, the paper discusses the network of relations between scientific literary studies sensu stricto and literary criticism.

Głow iń s ki, „Poeci i inni” Jana Błońskiego, s. 119, 121.

Głowińs ki, Poetyka małoobrazkowa, s. 118

M. Głow iń s ki, Poezja, czyli sztuka myślenia. „Twórczość” 1960, nr 7, s. 65.

M. Głow iń ski, Czachorowskiego wiersze mazowieckie. „Współczesność” 1961, nr 15, s. 6. 